\section{Phythochemical screening and antimicrobial activity of essential oil from Lippia gracillis}

\author{
Vanessa Bitu, ${ }^{1,2}$ Marco Antônio Botelho, ${ }^{1,3}$ José G. M. da \\ Costa, ${ }^{1}$ Fabiola F. G. Rodrigues, ${ }^{1}$ Helenicy N. H. Veras, ${ }^{1}$ Karine \\ T. Martins, ${ }^{2}$ Aarão Lyra, ${ }^{3}$ Giselle Gasparino Coluchi, ${ }^{3}$ Ronaldo \\ Sousa Ruela, ${ }^{3,4}$ Dinalva Brito Queiroz, ${ }^{4}$ Jullyana de Souza \\ Siqueira, ${ }^{5}$ Lucindo J. Quintans-Junior ${ }^{*, 5}$
}

\author{
${ }^{1}$ Programa de Pós-graduação em Bioprospecção Molecular, Departamento de \\ Química Biologica, Laboratório de Pesquisa em Produtos Naturais, Universidade \\ Regional do Cariri, Brazil, \\ ${ }^{2}$ Unidade de Saúde, Faculdade de Ciências Aplicadas Dr. Leão Sampaio, Brazil, \\ ${ }^{3}$ Programa de Pós-graduação em Odontologia, Laboratório de Biotecnologia, \\ Universidade Potiguar, Brazil, \\ ${ }^{4}$ Departamento de Biotecnologia, Evidence Pharmaceuticals, Brazil, \\ ${ }^{5}$ Departamento de Fisiologia, Universidade Federal de Sergipe, Brazil.
}

\begin{abstract}
The chemical composition of the essential oil obtained from the fresh and dried leaves of Lippia gracillis Schauer, Verbenaceae, was analyzed by gas chromatography and gas chromatography/mass spectrometry (GC/MS). The yield of essential oil extracted from the dried leaves was significantly higher $(p<0.05)$ when compared to the fresh leaves. Seventeen components were identified. The monoterpenes and sesquiterpene hydrocarbons with $96.26 \%(\mathrm{w} / \mathrm{w})$ of the total oil obtained of fresh leaves and $86.99 \%(w / w)$ of the total oil obtained of dried leaves were the principal compound groups. Thymol was observed dominant $(44.42 \%$; $21.3 \%)$, followed by carvacrol $(22.21 \% ; 21.30 \%)$, p-cymene $(6.23 \% ; 8.58 \%)$, $\alpha$-pinene $(5.65 \% ; 19.42 \%), \beta$-caryophyllene $(5.61 \% ; 3.57 \%)$ and other minor constitutes, respectively. Microbiological results obtained by agar diffusion method, micro dilution method and minimum inhibitory concentration (MIC) showed that the essential oil has a relevant antimicrobial activity against E. coli (ATCC 10536), E. coli (Ec 27), Pseudomonas aeruginosa (ATCC 15442), S. aureus (ATCC 12692) and $S$. aureus (Sa 358), with their inhibition zones ranging from 9 to $13 \mathrm{~mm}$ and the MIC ranging from 64 to $512 \mu \mathrm{g} / \mathrm{mL}$.
\end{abstract}

Revista Brasileira de Farmacognosia Brazilian Journal of Pharmacognosy 22(1): 69-75, Jan./Feb. 2012

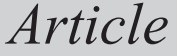

Received 12 Jan 2011

Accepted 4 May 2011 Available online 23 Sep 2011

Keywords: antimicrobial activity essential oil GCMS

Lippia gracillis monoterpene sesquiterpenes

ISSN 0102-695X http://dx.doi.org/10.1590/S0102$695 \times 2011005000173$

\section{Introduction}

The increasing resistance developments with available antimicrobials have drawn the attention of the scientific community to search for new and effective drugs from natural origin (Botelho et al., 2007a). Essential oils exert many properties such as antinociceptive (Franco et al., 2011), anticonvulsant (Oliveira, 2009), cardiovascular effects (Menezes et al., 2010), antimicrobial activity against cariogenic bacteria (Botelho et al., 2009a) and fungal filaments as well (Botelho et al., 2007b). Some studies point out that those plant-derived essential oils may be an effective alternative to overcome microbial resistance (Botelho et al., 2008).

These components are very versatile and they were mainly used for flavouring, fruit beverages, confectioneries, soft drinks, perfume, soaps, cosmetics, household products and pharmaceutical industry (Botelho et al., 2007b). They were also used in medical treatments and were known for exhibiting antimicrobial properties such as antifungal, antibacterial, antiviral and antiparasite (Fuselli et al., 2008; Botelho et al., 2007c; Botelho et al.,2009a).

Lippia gracillis Schauer, Verbenaceae, popularly known as "alecrim-de-tabuleiro", is a typical shrub commonly grown in the Northeast of Brazil. This species produces an essential oil (EO) rich in thymol and carvacrol, which has a potent antimicrobial activity against fungi and bacteria. It is one of the widely used substances in Brazilian traditional medicine, in the Northeast of Brazil for skin cuts, insect bites and sore throat (Botelho et al., 2008).

Previous studies have described the larvicidal property of Lippia essential oil (Carvalho et al., 2003). 
Recently, quinones from Lippia sidoides EO have been described to possess cytotoxic activity (Costa et al., 2001). Scientific evidence also suggests that the essential oil may be useful for oral hygiene and in the prevention of dental disorders such as caries and gingivitis (Botelho et al., 2007b; Botelho et al., 2009a). However, the in vitro activity against pathogens related to other diseases has not been so far reported. Thus, any treatment that would eliminate or substantially reduce colonization by these types of bacteria would likely have a strong impact and it would be beneficial for human health.

The aim of this study was to evaluate the chemical composition and the antibacterial activity of Lippia gracillis essential oil (LGEO) extracted from fresh and dried leaves against pathogens related to many human infections such as food spoilage, food safety and persistent hospital infection, since these organisms have now gained more importance due to increased concerns about safety in food and better quality of life. In addition, we studied the phytochemical composition of the essential oils by GC-MS analysis.

\section{Material and Methods}

\section{Plant material and extraction}

Leaves of Lippia gracillis Schauer, Verbenaceae, were collected in the month of January/2009 in the Medicinal Garden of the Regional University Cariri in Crato (CE). A representative sample was classified and deposited in the Herbarium Prisco Bezerra of the Universidade Federal do Ceará, under number 44456.

The leaf essential oil was extracted using a modified Clevenger apparatus (Botelho et al., 2007c) by the hydro-distillation technique. The essential oils extracted from fresh leaves (FL LGEO, $77 \mathrm{~g}$ ) and dried leaves (DL LGEO, $35.6 \mathrm{~g}$ ) were obtained by hydrodistillation using Clevenger type apparatus for a period of $2 \mathrm{~h}$, resulting in a yielding of 0.56 and $2.64 \%$ respectively. Then the oil were collected, dried with anhydrous sodium sulfate $\left(\mathrm{Na}_{2} \mathrm{SO}_{4}\right)$, filtered and stored under refrigeration until analysis. After extraction, the volume of $L$. gracillis essential oil (LGEO) obtained in both extractions was measured and the essential oil conditioned in hermetically sealed glass containers with rubber lids, covered with aluminum foil to protect the contents from light and kept under refrigeration at $8{ }^{\circ} \mathrm{C}$ until used.

\section{GC-MS analysis}

The composition of the essential oil was investigated by $\mathrm{GC}$ and $\mathrm{GC} / \mathrm{MS}$. The analytical GC was carried out using a spectrometer Shimadzu GC-17A/IN QP5050A system (GC/MS): DB-5HT capillary column
(30 $\mathrm{m} \times 0.251 \mathrm{~mm})$, carrier gas: helium $1.7 \mathrm{~mL} / \mathrm{min}$; column pressure $107.8 \mathrm{kPa}$, linear velocity, $47.3 \mathrm{~cm} / \mathrm{sec}$, total flow $24 \mathrm{~mL} / \mathrm{min}$ carrier flow of $24 \mathrm{~mL} / \mathrm{min}$, injector temperature $270{ }^{\circ} \mathrm{C}$, detector temperature $290^{\circ} \mathrm{C}$, column temperature $60(2 \mathrm{~min})-180{ }^{\circ} \mathrm{C}(1 \mathrm{~min})$ at $4{ }^{\circ} \mathrm{C} / \mathrm{min}$, then 180 to $260^{\circ} \mathrm{C}$ to $10^{\circ} \mathrm{C} / \mathrm{min}(10 \mathrm{~min})$. Operating under an ionization energy of $70 \mathrm{eV}$ (electron impact ionization). The identification of components was based on spectral fragmentation, using standard computer library Wiley 229, plus two other arguments: the retention indices and comparison with literature data (Botelho et al., 2007c).

GC-MS analysis was carried out on the same chromatograph equipped with a Hewlett-Packard MS computerized system (Palo Alto, California, USA), Model 5971 A, ionization voltage $70 \mathrm{eV}$, electron multiplier 1300 $\mathrm{V}$, ion source temperature $280{ }^{\circ} \mathrm{C}$, mass range $\mathrm{m} / \mathrm{z} 35$ 450 , scanning interval $0.5 \mathrm{~s}$, scanning speed $1000 \mathrm{amu} / \mathrm{s}$. $\mathrm{GC}$ conditions were the same as above. Identification of components was based on computer matching with NIST107 and NIST21 libraries and comparisons of the Kovats index with those reported in literatures.

\section{Antimicrobial assay}

\section{Strains}

The essential oil was tested towards eight microorganisms S. flexineri (ATCC 12022), K. pneumoniae (ATCC 10031), B. cereus (ATCC 33018), E.coli (ATCC 10536), S.aureus (ATCC 12692) and P. aeruginosa (ATCC 15442) and two clinical isolates, S. aureus (Sa 358 ) and E. coli (Ec 27). These micro-organisms were provided by the Fiocruz and the Federal University of Paraíba.

Antimicrobial screening by the disk diffusion method

The antimicrobial activity of LGEO against pathogens was determined by standard Disk Susceptibility Tests (Botelho et al., 2007c) tested against Bacillus cereus (ATCC 33018), Escherichia coli (ATCC 25922), Pseudomonas aeruginosa (ATCC 15442), Shigella flexineri (ATCC 12022), Klebsiella pneumoniae (ATCC 10031) and Sthaphylococcus aureus (ATCC 12692) by using the agar diffusion method (Romeiro, 2001). The clinically isolated bacterial and inoculum of all strain was obtained from fresh colonies grown on Müeller Hinton agar plates. Each strain was inoculated into $5 \mathrm{~mL}$ of Müeller Hinton broth in order to obtain a concentration of $1.5 \times 108 \mathrm{CFU} / \mathrm{mL}$ (0.5 MacFarland) and incubated at 37 ${ }^{\circ} \mathrm{C}$ for $24 \mathrm{~h}$. After this period, they were replicated on Petri dish containing Müeller Hinton agar (MH). The plates containing the microorganisms were then perforated and the cavities were filled with $25 \mu \mathrm{L}$ of the oil solutions at 
$10,5,2.5,1.25,0.6$ and $0.3 \%$ concentrations. Trials were performed in triplicate and commercial antibiotic disks of chloramphenicol $(30 \mu \mathrm{g} /$ disk $)$ and tetracycline $(30 \mu \mathrm{g} /$ disk) were employed as positive controls, while DMSO was served as negative control. Halos of inhibition were measured $24 \mathrm{~h}$ after initial exposure. The results were expressed in milimilters: $<9 \mathrm{~mm}$, inactive; 9-12 $\mathrm{mm}$, partially active; $13-18 \mathrm{~mm}$, active; $>18 \mathrm{~mm}$, very active (Rios et al., 1998). evaluation)

Antimicrobial testing (quantitative antimicrobial

The antibacterial activities of essential oils of L. gracillis were evaluated by broth microdilution, based on document M7-A6 (NCCLS, 2003) to determine the minimum inhibitory concentration (MIC). Gram-negative and Gram-positive bacteria were tested concomitantly with five others bacterial strains, three strains default, E. coli (ATCC 10536), S. aureus (ATCC 12692) and P. aeruginosa (ATCC 15442) and two clinical isolates, S. aureus (Sa 358) and E. coli (Ec 27). Before the tests, the bacterial strains were inoculated in Brain Heart Infusion (BHI) 3.8\% during $24 \mathrm{~h}$ at $35 \pm 2{ }^{\circ} \mathrm{C}$. After this period, the microorganisms were diluted at 1:10 in BHI broth to obtain $10 \%$ final concentration of 104 cells $/ \mathrm{mL}$ (Botelho et al., 2007c). The samples to be tested were prepared in advance to obtain an initial concentration of $100 \mathrm{mg} / \mathrm{mL}$, and observed the following ratio: $100 \mathrm{mg}$ of sample solubilized in $1 \mathrm{~mL}$ of dimethyl sulfoxide (Merck, Darmstadt, Germany). From this merger, was made a 1:10 dilution in sterile distilled water $(10 \mathrm{mg} / \mathrm{mL})$, and then it was diluted in the same way to $1024 \mu \mathrm{g} / \mathrm{mL}$. After wards, serial dilutions were $1: 1$ in distilled water, resulting in concentrations from 512 to 4 $\mu \mathrm{g} / \mathrm{mL}$.

Samples of essential oils obtained were prepared from fresh and dried leaves and used small volumes distributed in sterile microplate wells. The samples were prepared in double concentration $(1024 \mu \mathrm{g} / \mathrm{mL})$ compared with the initial concentration and defined volumes of 100 $\mathrm{mL}$ and then were serially diluted $1: 2$ in $10 \%$ Brain Heart Infusion broth. Each well with $100 \mu \mathrm{L}$ of culture medium was placed a sample of bacterial suspension diluted at $1: 10$. Resazurin $(0.01 \%)$ was used as revealing reagent in the volume of $25 \mu \mathrm{L} /$ well. The negative control was performed with BHI, while the positive control was broth plus inoculum. The minimum inhibitory concentration (MIC) was defined as the lowest concentration able to completely inhibit microbial growth in microdilution wells detected at the naked eye. The reading of the results for MIC determination was considered positive for the wells that kept the blue color and those who had negative staining red.

\section{Statistical analysis}

Each parameter was tested in at least triplicate. Conventional statistical methods were used to calculate means and standard deviations. Statistical significance was determined by analysis of variance and subsequent Dunnett's t-test $(p<0.05)$. The analysis was performed using SPSS statistical software.

\section{Results and Discussion}

Analysis by GC/MS of essential oil of fresh leaves (FL LGEO) allowed the identification of a total of seventeen different compounds, as revealed by Table 1 , the principal components of the FL LGEO were thymol was observed dominant $(44.42 \%)$, followed by carvacrol $(22.21 \%), p$-cymene $(6.23 \%), \alpha$-pinene (5.65\%), $\beta$-caryophyllene $(5.61 \%)$ and other minor constitutes, which represented $96.26 \%$ of the total essential oil, distributed as thirteen monoterpenes and four sesquiterpenes.

Table 1. Chemical composition of essential oil of Lippia gracillis essential oil from fresh and dried leaves.

\begin{tabular}{lccccc}
\hline \multirow{2}{*}{\multicolumn{1}{c}{ Components }} & \multirow{2}{*}{${ }^{\mathrm{b}} \mathrm{KI}_{\mathrm{Exp}}$} & \multicolumn{2}{c}{ FL LGEO } & \multicolumn{2}{c}{ DL LGEO } \\
\cline { 3 - 6 } & & ${ }^{\mathrm{a} T}$ & $(\%)$ & ${ }^{\mathrm{a} T}$ & $(\%)$ \\
\hline$\alpha$-thujene & 927 & 7.66 & 0.47 & - & - \\
$\alpha$-pinene & 931 & 10.96 & 5.65 & 10.64 & 19.42 \\
$\beta$-pinene & 965 & 12.43 & 0.33 & 12.42 & 0.83 \\
myrcene & 992 & 12.69 & 1.63 & 12.68 & 2.00 \\
$\alpha$-terpinene & 1012 & 13.78 & 0.61 & 13.78 & 0.79 \\
$p$-cymene & 1028 & 13.88 & 6.23 & 13.87 & 8.58 \\
limonene & 1033 & 14.25 & 0.39 & 14.24 & 0.83 \\
$\gamma$-terpinene & 1288 & 16.45 & 2.83 & 15.25 & 3.51 \\
4-terpineol & 1181 & 19.48 & 3.27 & 19.48 & 0.40 \\
thymol-methyl ether & 1230 & 21.29 & 0.63 & 21.27 & 3.46 \\
thymol-methyl ether & 1230 & 21.29 & 0.63 & 21.27 & 3.46 \\
carvacrol-methyl ether & 1248 & 21.67 & 0.74 & 21.66 & 0.64 \\
thymol & 1288 & 23.14 & 44.42 & 23.01 & 21.30 \\
carvacrol & 1296 & 23.45 & 22.21 & 23.36 & 20.85 \\
$\beta$-caryophylene & 1414 & 28.43 & 5.61 & 28.40 & 3.57 \\
$\alpha$-humulene & 1434 & 29.44 & 0.45 & 29.44 & 0.27 \\
$\delta$-cadinene & 1525 & 31.31 & 0.26 & 31.31 & 0.54 \\
caryophillene oxide & 1577 & 33.37 & 0.51 & - & - \\
\hline \multicolumn{1}{c}{ Total } & & 96.26 & & 86.99 \\
\hline
\end{tabular}

${ }^{\mathrm{a}} \mathrm{RT}$ : retention time; ${ }^{\mathrm{b}}$ relative retention indices experimental: $n$-alkanes were used as reference points in the calculation of relative retention indices. FL LGEO: Fresh leaves of Lippia gracillis essential oil. DL LGEO: Dried leaves of Lippia gracillis essential oil.

The yield of $L$. gracillis oil extracted from the dried leaves was considerably higher $(p<0.05)$ than that obtained from fresh leaves, ranging in average of 2.64 and $0.56 \%$ respectively. The volatile constituents often 
represent a mixture of monoterpene and sesquiterpene hydrocarbons and their oxygenated derivatives including: aldehydes, ketones, acids, alcohols and esters (Mondello et al., 2005). Generally, volatile essential oils containing raging from $85-99 \%$ and $1-15 \%$ non-volatile components (Njoroge etal., 2005). Regarding the chemical composition of DL LGEO, using the same analytical process, we could identify $86.99 \%$ of its chemical constitution, corresponding to fifteen compounds (Table 1). Of this total are reported: non-oxygenated monoterpenes, oxygenated monoterpenes and non-oxygenated sesquiterpenes. In this volatile oil were found in greater quantity thymol $(21.30 \%)$, carvacrol $(20.85 \%), \alpha$-pinene $(19.42 \%)$ and p-cymene $(8.58 \%)$.

In the preliminary test of susceptibility for evaluation of antibacterial activity, essential oils extracted from fresh and dried leaves presented activity against $S$. aureus, B. cereus, S. flexineri, P. aeruginosa and it proved ineffective against $E$. coli and $K$. pneumoniae. These results agree with those in the literature that report a minor susceptibility of Gram-negative compared to the plant extracts (Burt, 2004). The largest diameters of inhibition zones were observed against $S$. aureus, inhibited at concentrations of 10 and $5 \%$ with inhibition halos of 12 and $9 \mathrm{~mm}$ respectively (Table 2).

A recent study showed the promising antistaphylococcal property of $L$. sidoides essential oil, thus it is reasonable to speculate the possibility of the rational use of this substance as an alternative antibacterial agent (Oliveira et al., 2006), in this study the findings does not present statistically significance differences between the activity of the oils tested against $S$. aureus e $P$. aeruginosa at $10 \%$ concentration. However, when compared to standard antibiotics, the diameters of inhibition zone presented a considerably higher activity of both oils against $P$. aeruginosa, when compared to chloramphenicol.

The data indicated that the two types of essential oil exhibited varying levels of antimicrobial activity against the investigated microorganisms Table 3 . Through antimicrobial screening, the essential oil from dried leaves (DL LGEO) was more effective against $S$. flexineri and B. cereus when compared to the fresh leaves essential oil (FL LGEO). This activity probably is related to large amounts of sesquiterpenoids oxygen present in the dried leaves essential oil (Botelho et al., 2007c).

The in vitro antimicrobial activity of LGEO against the microorganisms and its potentials activity were qualitatively and quantitatively assessed by microdilution methodology and MIC values. The data obtained from this method indicated that the LGEO displayed a variable degree of antimicrobial activity on different tested strains (Table 4). The highest activity of this essential oil was observed against $E$. coli (ATCC 10536), with a MIC of $64 \mu \mathrm{g} / \mathrm{mL}$ for the FL LGEO and $128 \mu \mathrm{g} / \mathrm{mL}$ for the DL LGEO.

Through the statistical analysis it was shown that the values of the antimicrobial activity of the essential oil extracted from the fresh leaves presented a statistical significant difference when compared to the dried leaves activity. The essential oil also exhibited moderate activity against E. coli, evidenced by the MIC of 128 and $256 \mu \mathrm{g} /$ $\mathrm{mL}$, respectively.

Results of the MIC are presented in Table 4. The data indicated that the two types of essential oil exhibited varying levels of antimicrobial activity against the investigated microorganisms. The inhibitory properties of the essential oil from fresh leaves were observed within a range of MIC concentrations ranging from 64 to $512 \mu \mathrm{g} / \mathrm{mL}$. P. aeruginosa (ATCC 15442) showed similar susceptibility to the investigated oils, with MIC of 512 $\mu \mathrm{L} / \mathrm{mL}$.

The chemical compositions of essential oils in the present study, was consistent with other reports (Packer \& Luz, 2007; Costa et al., 2008; Botelho et al., 2009b). In fact, essential oils contents and compositions could differ greatly even in the same genus, as well as in different ripening stage and different organs (Tirado et al.,1995; Stashenko et al., 1996). In Lippia sidoides essential oil from Fortaleza, Ceará, Brazil (Botelho et al., 2007c), monoterpene hydrocarbons constituted $97.5 \%$ in the essential oils, with carvacrol $(11.3 \%)$,

Table 2. Antimicrobial activity in millimeters of Lippia gracillis essential oil from fresh leaves (FL LGEO), determined by direct contact method.

\begin{tabular}{|c|c|c|c|c|c|}
\hline \multirow{2}{*}{ Microorganism } & \multicolumn{5}{|c|}{ Inhibition zones $(\mathrm{mm} \pm \mathrm{SD})$} \\
\hline & FL LGEO 5\% & FL LGEO 5\% & $\mathrm{TE}(30 \mu \mathrm{g})$ & CHL $(30 \mu \mathrm{g})$ & $\operatorname{DMSO}(5 \%)$ \\
\hline E. coli 25922 & - & - & - & $7+0.47$ & - \\
\hline S. aureus 12692 & $9+0.96$ & $12.33+0.47^{\mathrm{c}}$ & $20+0.96$ & $18+0.47$ & - \\
\hline P. aeruginosa 15442 & - & $11.33+0.96^{\mathrm{b}}$ & $13+0.96$ & $6+0.96$ & - \\
\hline S. flexineri 12022 & - & $11+0.47^{\mathrm{a}}$ & $21+0.47$ & $14+0.96$ & - \\
\hline K. pneumoniae 10031 & - & - & - & $9+0.96$ & - \\
\hline B. cereus 33018 & - & $11++0.96 \mathrm{~d}$ & $22+0.47$ & $21+0.47$ & - \\
\hline
\end{tabular}

-: no inhibition zone was observed; ${ }^{\text {a-d }}$ Stand for the significance of difference $(p<0.05)$ based on Tukey's test; CHL: chloramphenicol and TE: tetracycline; FL LGEO: Fresh leaves of Lippia gracillis essential oil; DL LGEO: Dried leaves of Lippia gracillis essential oil. 
Table 3. Antimicrobial activity in millimeters of Lippia gracillis essential oil from dried leaves (DL LGEO), determined by direct contact method.

\begin{tabular}{|c|c|c|c|c|c|}
\hline \multirow{2}{*}{ Microorganism } & \multicolumn{5}{|c|}{ Inhibition zones $(\mathrm{mm} \pm \mathrm{SD})$} \\
\hline & DL LGEO 5\% & DL LGEO 5\% & $\mathrm{TE}(30 \mu \mathrm{g})$ & CHL $(30 \mu \mathrm{g})$ & DMSO (5\%) \\
\hline E. coli 25922 & - & - & - & $6+0.96$ & - \\
\hline S. aureus 12692 & - & $12.33+0.47$ & $19+0.47$ & $18+0.96$ & - \\
\hline P. aeruginosa 15442 & _ & $11.33+0.47$ & - & $6+0.96$ & - \\
\hline S. flexineri 12022 & - & $12+0.96$ & 14 & $12+0.47$ & - \\
\hline K. pneumoniae 10031 & - & _ & $9+0.96$ & $15+0.47$ & - \\
\hline B. cereus 33018 & _ & $13+0.96$ & $7+0.96$ & $23+0.96$ & - \\
\hline
\end{tabular}

-: no inhibition zone was observed; a-dStand for the significance of difference $(p<0.05)$ based on Tukey's test; CHL: chloramphenicol and TE: tetracycline; FL LGEO: Fresh leaves of Lippia gracillis essential oil; DL LGEO: Dried leaves of Lippia gracillis essential oil.

Table 4. Antimicrobial activity expressed as minimum inhibitory concentration $(\mu \mathrm{g} / \mathrm{mL})$ of LGEO against tested bacteria.

\begin{tabular}{lcc}
\hline & Microorganism & \multicolumn{2}{c}{ MIC $(\mu \mathrm{g} / \mathrm{mL})$} \\
\cline { 2 - 3 } & FL LGEO* & DL LGEO\# \\
\hline E. coli (ATCC 10536) & 64 & 128 \\
E. coli (Ec 27) & 128 & 256 \\
P. aeruginosa (ATCC 15442) & 512 & 512 \\
S. aureus (ATCC 12692) & 128 & 256 \\
S. aureus (Sa 358) & 512 & 512 \\
\hline
\end{tabular}

"FL LGEO: Fresh leaves of Lippia gracillis essential oil; "DL LGEO: Dried leaves of Lippia gracillis essential oil.

$\alpha$-terpinene (1.8\%), and $\alpha$-pinene $(0.5 \%)$ as the main compounds, while contents of esters $(0.4 \%)$, alcohols $(0.3 \%)$ and ketones $(0.1 \%)$ with a minor concentration when compared to LGEO, represented $1.06 \%, 0.74 \%$, and $0.59 \%$, respectively.

Other interesting topic to notice is when carvacrol and thymol contents where compared, the data reach a statistical significant differences when compared fresh with dried leaves essential oils.

The application of the essential oils in fine perfumery is very interesting, therefore, the LGEO constituents might be valuable for the flavouring of foods, chewing gums, sweets, teas and energy drinks. In cosmetics, the investigated agents may contribute with characteristic that might be used in shampoos, soaps, shower gels, body lotions and tooth pastes (Ngassoum et al., 2004; Fisher \& Phillips, 2008).

The LGEO presented significant activity against $S$. aureus and E. coli. These activities might be produced by a single major compound or by the synergistic or antagonistic effect of various minor compounds present in the tested oils.

Thymol, which was found to be in appreciable amounts in the LGEO, it has been reported to have a wide range of antibacterial and antifungal activity (Pattnaik et al.,1997; Botelho et al. 2007c; Fuselli et al., 2008). Botelho et al. (2007c) have shown that $C$. albicans, was susceptible to Lippia sidoides essential oil and pure thymol and carvacrol. They also tested the antimicrobial activity of Lippia sidoides leaf oil (56.7\%) thymol and (16.7\%) carvacrol as the major components against cariogenic bacteria and fungi, found either similar activity. Other than thymol and carvacrol, minor constituents such as $\alpha$-pinene and $p$-cimene present in the essential oil of Lippia gracillis might also contributed to the antimicrobial activity, such as $\alpha$-terpineol that has been reported to inhibit the growth of quite a number of bacteria and fungi that include E. coli, S. aureus, Bacillus spp. and C. albicans (Magwa et al., 2006).

The antimicrobial activity of oil from $S$. officinalis and $S$. triloba was suggested to be the presence of $\alpha$-pinene, $\beta$-pinene, $\alpha$-terpineol, terpinen-4-ol, $\beta$-caryophyllene, $\alpha$-phellandrene and $\rho$-cymene (Dorman $\&$ Deans, 2000). $\alpha$-pinene and $\beta$-pinene were active against the fungi Verticillium fungicola and Trichoderma harzianum and the bacterium Pseudomonas tolaasii (Sokovic \& Van Griensven, 2006).

The antifungal effect of M. glyptostroboides essential oil against tested fungi could be attributed to presence of $\alpha$-pinene, $\alpha$-thujene and caryophyllene oxide (Bajpai et al., 2007). The antifungal activity of $\alpha$-pinene was reported when Pistacia lentiscus essential oil was evaluated (Matasyoh et al., 2007).

It is well established that microbes can negatively affect the host health status. E. coli and $S$. aureus are the most common bacteria that infect humans through generations. During the microbial invasion the released metabolism byproducts can facilitate invasion 
and can cause significant tissue damage followed by other vascular phenomena mediated by inflammatory compounds (Botelho et al., 2007a).

Within the limitation of this study, the findings suggest that the essential oils tested presented a relevant antimicrobial activity against E. coli, P. aeruginosa and $S$. aureus. Among the microorganisms related to gastrointestinal infection, E. coli presented the highest sensitivity to the tested compounds.

Our present results demonstrated that essential oil extracted from LGEO was rich in thymol, carvacrol, myrcene, $\alpha$-pinene and other components, which plays positive roles in inflammatory diseases and also has a financial interesting for the cosmetic industry for different applications in perfumes, creams and soaps. The essential oil also showed a wide spectrum of antimicrobial activity against the tested microorganisms suggesting that this essential oil would be a natural flavor additive substituting chemicals in food preservation.

\section{Acknowledgements}

This work was financially supported by the Brazilian Council of Technological Development (Proc. CNPq 452315/2009-3, 558017/2008-8, 561940/2008-8, $452125 / 2008-1,402074 / 2008-4,577214 / 2008-0)$ to the recepient MAB.

We gratefully acknowledge the technical cooperation of Prof. Sonia Izabel Romero de Souza (Leão Sampaio Faculty, Juazeiro do Norte-CE).

Special thanks to Rejane Carvalho (Postgraduation Program in Odontology-UNP), Elber Bezerra de Menezes (Evidence Pharmaceuticals, Fortaleza,CEBrazil),Henrique Douglas Coutinho and Irwin Alencar (URCA, Crato-CE) for infrastructure and technical support. The authors gratefully acknowledge the Dean Prof. Sâmela Soraya Gomes de Oliveira (UNP).

\section{References}

Bajpai VK, Rahman A, Kang SC 2007. Chemical composition and anti-fungal properties of the essential oil and crude extracts of Metasequoia glyptostroboides Miki ex Hu. Ind Crop Prod 26: 28-35.

Botelho MA, Rao VS, Carvalho CB, Bezerra-Filho JG, Fonseca SG, Vale ML, Montenegro D, Cunha F, Ribeiro RA, Brito GA 2007a. Lippia sidoides and Myracrodruon urundeuva gel prevents alveolar bone resorption in experimental periodontitis in rats. $J$ Ethnopharmacol 113: 471-478.

Botelho MA, Bezerra Filho JG, Correa LL, Fonseca SG, Montenegro D, Gapski R, Brito GA, Heukelbach J 2007b. Effect of a novel essential oil mouthrinse without alcohol on gingivitis: a double-blinded randomized controlled trial. J Appl Oral Sci 15: 175-180.
Botelho MA, Nogueira NA, Bastos GM, Fonseca SG, Lemos TL, Matos FJ, Montenegro D, Heukelbach J, Rao VS, Brito GA 2007c. Antimicrobial activity of the essential oil from Lippia sidoides, carvacrol and thymol against oral pathogens. Braz J Med Biol Res 40: 349-356.

Botelho MA, Rao VS, Montenegro D, Bandeira MA, Fonseca SG, Nogueira NA, Ribeiro RA, Brito GA 2008. Effects of a herbal gel containing carvacrol and chalcones on alveolar bone resorption in rats on experimental periodontitis. Phytother Res 22: 442-449.

Botelho MA, dos Santos RA, Martins JG, Carvalho CO, Paz MC, Azenha C, Ruela RS, Queiroz DB, Ruela WS, Marinho G, Ruela FI 2009a. Comparative effect of an essential oil mouthrinse on plaque, gingivitis and salivary Streptococcus mutans levels: a double blind randomized study. Phytother Res 23: 1214-1219.

Botelho MA, Martins JG, Ruela RS, I R, Santos JA, Soares JB, França MC, Montenegro D, Ruela WS, Barros LP, Queiroz DB, Araujo RS, Sampio FC 2009b. Protective effect of locally applied carvacrol gel on ligatureinduced periodontitis in rats: a tapping mode AFM study. Phytother Res 23: 1439-1348.

Burt S 2004. Essential oils: their antibacterial properties and potential applications in foods-a review. Int $J$ Food Microbiol 94: 223-253

Carvalho AF, Melo VM, Craveiro AA, Machado MI, Bantim MB, Rabelo EF 2003. Larvicidal activity of the essential oil from Lippia sidoides Cham. against Aedes aegypti Linn. Mem Inst Oswaldo Cruz 98: 569-571.

Costa JGM, Rodrigues FFG, Angelico EC, Santos NKA, Pereira CKB, Souza EO, Caldas GFR, Silva MR, Mota ML, Santos PF 2008. Composição química e avaliação da atividade antibacteriana e toxicidade do óleo essencial de Croton zehntneri (variedade estragol). Rev Bras Farmacogn 18: 583-586.

Costa SM, Lemos TL, Pessoa OD, Pessoa C, Montenegro RC, Braz-Filho R 2001. Chemical constituents from Lippia sidoides and cytotoxic activity. J Nat Prod 64: 792795.

Craveiro AA, Matos FJA, Alencar JW 1976. A simple and inexpensive steam generator for essential oils extraction. J Chem Educ 53: 652.

Dorman HJD, Deans SG 2000. Antimicrobial agents from plants: Antibacterial activity of plant volatile oils. $J$ Appl Microbiol 88: 308-316.

Fisher K, Phillips C 2008. Potential antimicrobial uses of essential oils in food: is citrus the answer? Trends Food Sci Tech 19: 156-164.

Franco CRP, Antoniolli AR, Guimarães AG, Andrade DM, Jesus HCR, Alves PB, Bannet LE, Patrus AH, Azevedo EG, Queiroz DB, Quintans-Júnior LJ, Botelho MA 2011. Bioassay-guided evaluation of antinociceptive properties and chemical variability of the essential oil of Hyptis fruticosa. Phytother Res 25 in press, (DOI: 10.1002/ptr.3455). 
Fuselli SR, De la Rosa SBG, Eguaras MJ, Fritz R 2008. Chemical composition and antimicrobial activity of Citrus essences on honeybee bacterial pathogen Paenibacillus larvae, the causal agent of American foulbrood. World J Microbiol Biotechnol 24: 2067-2072.

Magwa ML, Gundidza M, Gwerua N, Humphrey G 2006. Chemical composition and biological activities of essential oil from the leaves of Sesuvium portulacastrum. J Ethnopharmacol 103: 85-89.

Matasyoh JC, Kiplime JJ, Karubiu NM, Hailstorks TP 2007. Chemical composition and antimicrobial activity of essential oil of Tarchonanthus camphorates. Food Chem 101: 1183-1187.

Menezes IAC, Moreira IJA, De Paula JWA, Blank AF, Antoniolli AR, Quintans-Júnior LJ, Santos MRV 2010. Cardiovascular effects induced by Cymbopogon winterianus essential oil in rats: involvement of calcium channels and vagal pathway. $J$ Pharm Pharmacol 62: 215-221.

Mondello L, Casilli A, Tranchida PQ, Dugo P, Dugo G 2005. Comprehensive two-dimensional GC for the analysis of citrus essential oils. Flavour Fragr J 20: 136-140.

National Committee for Clinical Laboratory Standards 2003. Methods for dilution antimicrobial susceptibility tests of bacteria that grow aerobically. Wayne: NCCLS.

Ngassoum MB, Ousmaila H, Ngamo LT, Maponmetsem PM, Jirovetz L, Buchbauer G 2004. Aroma compounds of essential oils of two varieties of the spice plant Ocimum canum Sims from northern Cameroon. J Food Compos Anal 17: 197-204.

Njoroge SM, Koaze H, Karanja PN, Sawamura M 2005. Volatile constituents of redblush grapefruit (Citrus paradisi) and pummelo (Citrus grandis) peel essential oils from Kenya. J Agr Food Chem 53: 9790-9794.

Oliveira JS, Porto LA, Estevam CS, Siqueira RS, Alves PB, Niculau ES, Blank AF, Almeida RN, Marchioro M, Quintans-Júnior LJ 2009. Phytochemical screening and anticonvulsant property of Ocimum basilicum leaf essential oil. BLACPMA 8: 195-202.

Oliveira RAG, Lima EO, Vieira WL, Freire KRL, Trajano VN, Lima, IO, Souza EL, Toledo MS, Silva-Filho RN 2006. Estudo da interferência de óleos essenciais sobre a atividade de alguns antibióticos usados na clínica. Rev Bras Farmacogn 16: 77-82.

Packer JF, Luz MMS 2007. Método de avaliação e pesquisa da atividade antimicrobiana de produtos de origem natural. Rev Bras Farmacogn 17: 345-353.

Pattnaik SS, Bapaji J, Kole CR 1997. Antibacterial antifungal activity of aromatic constituents of essential oils. Microbios 358: 39-46.

Rios JL, Recio MC, Villar A 1998. Screening methods for natural products with antimicrobial activity: a review of the literature. J Ethnopharmacol 23: 127-149.

Romeiro RS 2001. Métodos em bacteriologia de plantas. Viçosa: Editora UFC.

Sokovic M, Van Griensven LJLD 2006. Antimicrobial activity of essential oils and their components against the three major pathogens of the cultivated button mushroom, Agaricus bisporus. Eur J Plant Pathol 116: 211-224.

Stashenko EE, Martínez R, Pinzdn MH, Ramfrez J 1996. Changes in chemical composition of catalytically hydrogenated orange oil (Citrus sinensis). J Chromatogr 752: 217-222.

Tirado CB, Stashenko EE, Combariza MY, Martinez JR 1995. Comparative study of Colombian citrus oils by highresolution gas chromatography and gas chromatographymass spectrometry. J Chromatogr 697: 501-513.

\section{*Correspondence}

Lucindo J. Quintans-Júnior

Departamento de Fisiologia, Universidade Federal de Sergipe 49000-100 São Cristóvão-SE, Brazil

lucindo@ufs.br; lucindo@pq.cnpq.br

Tel./Fax: 55792105 6645; +55 7921056474 